\title{
Cost of Unnecessary Repeat Requesting of Tests for HBsAg, Anti-HCV and Anti-HIV Screening in a University Hospital
}

\author{
Uygunsuz Tekrarlanan HBsAg, Anti-HCV and Anti-HIV Tarama Testlerinin Bir Üniversite \\ Hastanesine Maliyeti
}

\author{
Tayfur DEMIRAY1, Mehmet KOROĞLU1,2, Engin KARAKEÇE1, Ahmet ÖZBEK1,2, Mustafa ALTINDIŞ1,2
}

${ }^{1}$ Sakarya University Research and Training Hospital, Clinical Microbiology Laboratory, Sakarya, Turkey

2 Sakarya University Faculty of Medicine, Department of Medical Microbiology, Sakarya, Turkey

\begin{abstract}
Objective: Serological markers related to hepatitis B, hepatitis C and human immunodeficiency viruses are mainly used in the diagnosis of hepatitis $\mathrm{B}, \mathrm{C}$ and human immunodeficiency virus (HIV) infections, and determination of chronic or carrier state of patients. However, HBsAg, anti-hepatit C virus (HCV) and anti-HIV tests are also requested for public health surveillance, preoperative screening purposes and medical reports (individuals without hepatitis and/ or AIDS prediagnosis for non-diagnostic purposes). We aimed to investigate the cost of unnecessary repeat requesting of tests for $\mathrm{HBsAg}$, anti-HCV and anti-HIV screening which were repeated 2 or more times in a five-year-period ordered for non-diagnostic purposes. Materials and Methods: Patients tested for any medical reason for HBsAg, anti-HCV and anti-HIV during a five-year-period were evaluated retrospectively. Tests repeated in patients with viral hepatitis for medical reasons, those in accordance with predetermined viral hepatitis algorithms, and tests necessarily repeated by the laboratory were excluded.

Results: The number of at least one-time-repeated tests with all the positive or negative results in a five-year period was 38.822 for HBsAg, 38074 for anti-HCV and 23.332 for anti-HIV. The repeated tests constituted $20.2 \%$ of all tests. Noteworthy, there were even up to 20 times unnecessarily repeated tests.

Conclusion: Repeated HBsAg, anti-HCV and anti-HIV tests impose a significant financial burden on the national economy. The total cost of unnecessary repeat requesting of tests in our hospital in a five-year-period was found to be 6.489 USD. When a calculation was made according to the ratio of inappropriately repeated tests to total tests done in the whole country, the total financial loss was estimated as a huge value as 1.042.215 USD only for 3 test parameters. After controlling indications for tests, establishing control and warning steps in the social security systems and hospital automation networks, financial burden could be reduced to a much more reasonable levels.
\end{abstract}

Keywords: HbsAg, anti-HCV, anti-HIV, repeated tests, economic evaluation, cost savings
$0 z$

Amaç: Serolojik testler genellikle, viral hepatit/HIV enfeksiyonlarının tanısı ve hastaların kronik veya taşıyıcı durumlarının belirlenmesi için talep edilmektedir. Ancak, HBsAg, anti-HCV, anti-HIV testleri sağlıklı bireylerden, tarama amaçlı, preoperatif değerlendirme amaçlı ve sağlık raporlarının bir parçası olarak da talep edilmektedir. Bu çalışmada, beş yıllık dönemde 2 veya daha fazla sayıda uygunsuz sekilde tekrarlanan, tanısal amaçlı olmayan HBsAg, anti-HCV ve antiHIV testlerinin yol açtığı maliyetin araştıııması amaçlanmıştır. Gereç ve Yöntemler: Ocak-2009 ile Aralık 2013 arasındaki beş yıllık dönemde, Sakarya Üniversitesi Eğitim ve Araştırma Hastanesi'nde çalışlan HbsAg, anti-HCV ve anti-HIV testlerine ait sonuçlar retrospektif olarak değerlendirildi. Laboratuvar tarafından tekrarlanan testlerin yanısıra, hepatit ilişkili hastalıklara ait tıbbi nedenler veya önceden belirlenmiş viral hepatit tanı algoritmalar doğrultusunda tekrarlanan testler çalışma dışı bırakıldı.

Bulgular: Tüm pozitif ve negatif sonuçlar birlikte değerlendirildiğinde, beş yıllık dönemde en az bir kez tekrarlanan testlerin sayıları HBsAg için 38,822 , anti-HCV için 38,074 ve anti-HIV için 23,332 olarak belirlenmisstir. Tekrarlanan testlerin sayısı yapılan toplam testlerin \%20,2 oluşturmuştur. Dikkat çekici bir biçimde 20 kez uygunsuz tekrarlarının olduğu saptandı.

Sonuç: Uygunsuz biçimde tekrarlanan HBsAg, anti-HCV, anti-HIV testleri hastanemiz ülkemiz bütçesi üzerinde önemli bir mali yüke neden olmaktadır. Hastanemizde uygunsuz tekrarlanan testlerin toplam maliyeti, beş yıllık dönemde, 6,489 Amerikan doları olarak hesaplanmıștır. Uygunsuz tekrarlanan testlerin oranına göre ülke geneli için bir yansıtma yapıldığında, toplam finansal kayıp, sadece 3 test parametresi için 1,042,215 Amerikan doları olarak öngörülmüștür. Her ne kadar bir hastaneye ait veriler ile tüm ülke için çıkarımlar yapmak mantıksız gibi görünse de, bu veriler ile sağlık politikası yapanları, uygulayıcıları ve laboratuvar sorumlularını uyarmak mümkündür. Test istemleri yapilırken, uygun endikasyonları kontrol mekanizma ve algoritmalarının kurulması ve sosyal güvenlik sistemleri ile hastane otomasyon ağlarında uyarı içeren basamakların efektif biçimde işletilmesi, bu mali yükü çok daha makul seviyelere düşürülebilir. Anahtar Kelimeler: $\mathrm{HbsAg}$, anti-HCV, anti-HIV, tekrarlanan testler, ekonomik değerlendirme, maliyet tasarrufu 


\section{Introduction}

Serological markers related to hepatitis $B$, hepatitis $\mathrm{C}$ and human immunodeficiency virus (HIV) are mainly used in the diagnosis of hepatitis B and C and HIV infections. Specific algorithms are used for the detection of the acute, chronic or carrier state of the virus. Besides the systematic approach of diagnosis, $\mathrm{HBsAg}$, anti-hepatit $\mathrm{C}$ virus $(\mathrm{HCV})$ and anti-HIV tests are requested in conditions such as carrier screening programs, determination of risk groups, before surgery or other invasive procedures, job applications, and medical committee reports. These tests are repeated inappropriately due to deviations from diagnostic algorithms, inability to reach records in different health institutions, insufficient past medical records or the lack of alerting systems in hospital computer automation systems. As a result, increase in workload and costs in hospital settings arise $(1,2,3)$.

In this study, we aimed to investigate the amount of tests and the cost of unnecessary repeat requesting of test for HBsAg, anti-HCV and anti-HIV in a five-year period in our hospital. Also by using data from this study, we tried to make a crude estimation concerning the whole country about the amount and the financial burden of the unnecessary repeat requesting of the tests.

\section{Materials and Methods}

HBsAg, anti-HCV and anti-HIV test results in patients or healthy people attended to Sakarya University Training and Research Hospital for any health problem, medical intervention or medical reporting between 1 January 2009 and 31 December 2013 were retrospectively evaluated. Patients with a preliminary diagnosis of hepatitis, liver disease-related conditions and jaundice-related conditions were excluded from database searching. Diagnostic algorithms, which were proposed previously in the literature, were used to exclude test results of patients with preliminary diagnosis of hepatitis $(4,5)$. Test requested from infectious diseases and gastroenterology clinics, hemodialysis unit, and blood transfusion center were excluded from evaluation due to the reason that these clinics may repeat these tests on necessary indications. Any requests for these tests, which were repeated for medical reasons, and tests necessarily repeated by the laboratory, were also excluded. Results of repeated tests for the verification purposes were also excluded from the study. When the patient serology was changed during the evaluated period, that patient was not included in the study. Only HBsAg, anti-HCV and anti-HIV tests, which were requested for health surveillance, preoperative screening purposes and non-medical reports, such as work applications, medical committee reports, were included in the study.

Chemiluminescence microparticle immunoassay method (i1000/2000, Abbott, USA) is used for testing HBsAg, anti-HCV and anti-HIV parameters in our laboratory.

In the calculation of the financial burden; the Health Practice Communiqué, current in our country since 2013, and the Central Registration and Management System of the Ministry of Health were used for determination of the prices and quantities. The amount of tests used in a five-year period in hospitals run by the Ministry of Health was investigated, thus, tests done by university hospitals and private hospitals were not included in that number.

According to the current Health Practice Communiqué, the unit price of HBsAg and anti-HIV tests was 3.53 US \$ and the unit price of anti-HCV was 3.75 US \$. For conversion from Turkish Lira to US Dollar was made based on the exchange rate announced by the Central Bank of the Republic of Turkey on 31 December 2013 (http://www.tcmb.gov.tr/kurlar/201312/31122013.html). This study was approved by the ethics committee of Sakarya University, Faculty of Medicine.

\section{Results}

Repeated tests, which were requested prior to surgical or interventional procedures, constituted $87.7 \%$ of all repeated tests. The total number of tests done for HBsAg, anti-HCV and anti HIV screening was 180681, 129339 and 136856, respectively. The number of repeated HBsAg, anti-HIV and anti-HCV parameters and patients, regardless of the test results, within the five-year period is given in Table 1. The number of repeated tests in the five-year period, regardless of the test result was 38822 for HBsAg, 38074 for anti-HCV and 23332 for anti-HIV. The number of repeated tests constituted $20.2 \%$ of all tests for HBsAg and anti-HCV and $16.6 \%$ of all tests for anti-HIV. Although very strict criteria were set for exclusion, which were explained in the materials and methods section, the large number of repeated tests was remarkable.

When the test results were positive, repeated tests and the number of patients within the five-year period are provided in Table 2. All these tests were regarded as inappropriate and unnecessary according to the exclusion criteria. Interestingly and noteworthy, there were even up to 20 times unnecessary repeats. The total number of these tests were 1446, 367 and 6 tests for HBsAg, anti$\mathrm{HCV}$, and anti-HIV, respectively.

Table 1. Number of repeated tests for HBsAg, anti-HCV and, anti-HIV in five-year period (regardless of test results)

\begin{tabular}{|c|c|c|c|c|}
\hline Test & $\begin{array}{c}\text { Number of } \\
\text { Repeat }\end{array}$ & $\begin{array}{l}\text { Number of } \\
\text { Patients }\end{array}$ & Percentage & $\begin{array}{c}\text { Number of } \\
\text { Repeated Tests }\end{array}$ \\
\hline \multirow{6}{*}{$\mathrm{HBsAg}$} & - & 61419 & 79. 8 & - \\
\hline & 1 & 11185 & 14.5 & 22370 \\
\hline & 2 & 2725 & 3.5 & 8175 \\
\hline & 3 to 10 & 1554 & 2.0 & 7504 \\
\hline & 11 to 20 & 54 & 0.2 & 773 \\
\hline & Total & 76937 & 100 & 38822 \\
\hline \multirow{6}{*}{ Anti-HCV } & - & 59978 & 79.8 & - \\
\hline & 1 & 10941 & 14.6 & 21882 \\
\hline & 2 & 2666 & 3.5 & 7998 \\
\hline & 3 to 10 & 1535 & 2.0 & 7402 \\
\hline & 11 to 20 & 55 & 0.1 & 792 \\
\hline & Total & 75175 & 100 & 38074 \\
\hline \multirow{6}{*}{ Anti-HIV } & - & 48031 & 83.4 & - \\
\hline & 1 & 7118 & 12.4 & 14236 \\
\hline & 2 & 1530 & 2.7 & 4590 \\
\hline & 3 to 10 & 866 & 1.5 & 4254 \\
\hline & 11 to 20 & 18 & 0 & 252 \\
\hline & Total & 57563 & 100 & 23332 \\
\hline
\end{tabular}

HCV: Hepatit C virus, HIV: Human immunodeficiency virus

${ }^{*}$ First tests requests were not counted 


\begin{tabular}{|c|c|c|c|c|}
\hline Test & $\begin{array}{c}\text { Number of } \\
\text { Repeat }\end{array}$ & $\begin{array}{l}\text { Number of } \\
\text { Patients }\end{array}$ & Percentage & $\begin{array}{l}\text { Unnecessary and } \\
\text { Inapproprite Tests }\end{array}$ \\
\hline \multirow{6}{*}{ HBsAg } & - & 2109 & 78.3 & * \\
\hline & 1 & 427 & 15.9 & 854 \\
\hline & 2 & 98 & 3.6 & 294 \\
\hline & 3 to 10 & 56 & 2.1 & 260 \\
\hline & 11 to 20 & 3 & 0.1 & 38 \\
\hline & Total & 2693 & 100 & 1446 \\
\hline \multirow{6}{*}{ Anti-HCV } & - & 380 & 73.3 & * \\
\hline & 1 & 89 & 17.1 & 178 \\
\hline & 2 & 28 & 5.4 & 84 \\
\hline & 3 to 10 & 22 & 4.2 & 105 \\
\hline & 11 to 20 & 0 & 0 & 0 \\
\hline & Total & 519 & 100 & 367 \\
\hline \multirow{6}{*}{ Anti-HIV } & - & 13 & 81.2 & * \\
\hline & 1 & 3 & 18.8 & 6 \\
\hline & 2 & 0 & 0 & 0 \\
\hline & 3 to 10 & 0 & 0 & 0 \\
\hline & 11 to 20 & 0 & 0 & 0 \\
\hline & Total & 16 & 100 & 6 \\
\hline
\end{tabular}

*First tests requests were not counted

HCV: Hepatit C virus, HIV: Human immunodeficiency virus

Table 3. Financial costs of repeated tests in our hospital, and financial costs of unnecessarily and inappropriately repeated tests estimated for whole country in five-year period

\begin{tabular}{|l|c|c|c|}
\hline & HBsAg & Anti-HCV & Anti-HIV \\
\hline Unit price of the test & 3.53 \$ & 3.75 \$ & 3.53 \$ \\
\hline $\begin{array}{l}\text { Total tests done in } \\
\text { our hospital }\end{array}$ & 180681 & 129339 & 136856 \\
\hline $\begin{array}{l}\text { Unnecessary and } \\
\text { Inapproprite tests }\end{array}$ & 1446 & 367 & 6 \\
\hline $\begin{array}{l}\text { Financial cost in our } \\
\text { hospital }\end{array}$ & 5090 US \$ & 1376 US \$ & 21 US \$ \\
\hline $\begin{array}{l}\text { Total loss in our } \\
\text { hospital }\end{array}$ & \multicolumn{3}{|c|}{6489 US \$ } \\
\hline Tests done in Turkey & 29300632 & 20097171 & 19097677 \\
\hline $\begin{array}{l}\text { Unnecessary and } \\
\text { Inapproprite tests }\end{array}$ & 234495 & 57026 & 837 \\
\hline $\begin{array}{l}\text { Financial cost in } \\
\text { Turkey }\end{array}$ & 825421 US \$ 213847 US \$ & 2947 US \$ \\
\hline Total loss in Turkey ${ }^{\dagger}$ & 1042215 US \$ & \multicolumn{3}{|l}{} \\
\hline
\end{tabular}

${ }^{\dagger}$ Estimated values

HCV: Hepatit C virus, HIV: Human immunodeficiency virus

The total cost of unnecessary repeat tests in our hospital was calculated as 6489 US \$ in the five-year period. The ratio of unnecessary repeat tests to whole tests studied was found to be $1.6 \%, 0.4 \%$ and $0.008 \%$ for $\mathrm{HBsAg}$, anti-HCV, and anti-HIV, respectively. When a calculation was made according to the ratio of unnecessarily repeated tests to total tests done in the whole country, the total financial loss was estimated to be as a huge value as 1.042.215 US \$ only for 3 test parameters (Table 3 ).

\section{Discussion}

When a new surgical operation or interventional procedure is planned, the clinician may request HBsAg, anti-HCV and anti-HIV tests even if the previous results were negative. This situation is acceptable and repetitions of the tests are understandable. However, there is no scientific data available today to clearly define when to repeat these tests. For this reason, when analyzing the financial burden of repeated tests, repeated tests with negative results were not taken into account. However, we applied very large and strict criteria to exclude reasonable requests and, surprisingly, a large number of repeated tests were determined.

Before any surgical or interventional procedures, determination of serological status of the patient should be argued. The rate as high as $87.7 \%$ of the repeated tests is due to such test requests. Taking necessary infection control precautions, without determining the infectious status of the patients (except for major surgical procedures), may decrease the burden due to serological tests.

When tests with positive results were examined, the rate of two or more repeats in the five-year period was $21.7 \%$ for $\mathrm{HBsAg}$, $26.7 \%$ for anti-HCV, and $18.8 \%$ for anti-HIV, respectively. Anti-HCV assay was found to have the highest repetition rate (Table 2).

In our hospital, the rate of unnecessarily repeated HBsAg tests with previous positive results for the five-year period was $21.7 \%$ (Table 2). The burden on the budget of our hospitals with these rates is given in Table 3 . When these rates were reflected proportionally to the figures across the country; it was calculated that 234495 tests for HBsAg was consumed due to repeated work in the five-year period. When considering the average price of 3.52 USD, financial burden of these tests appeared as 82521 USD. The average cost of anti-HCV test was 3.75 USD, and the total number of unnecessarily repeated anti-HCV tests in the fiveyear period was calculated as 57026 for Turkey. The burden was determined to be 213847 USD. For anti-HIV testing, the country wasted 837 tests and 2947 USD in the five-year period. Since university hospitals and private hospitals were not included in the estimation, it is believed that financial loss would be much higher than calculated. Furthermore, in Turkey, doctors were paid in a simple salary system, unrelated to workload, thus this kind of financial burden was not added. Increased laboratory workload due to repeated tests should also be taken into account in calculating financial loss $(6,7)$. Although it seems illogical to reflect data from a single hospital to the whole country, it is possible to alert health policy makers, practitioners and laboratory workers.

In a report declared by The Ministry of Health of Turkey covering 24 hospitals in Ankara in 2013, it has been stated that hepatitis, HIV and TORCH testing expenses constituted about $10 \%$ of the total payment for all tests without specifying any criteria. Also it was stressed that HBsAg, anti-HCV and anti-HIV parameters were included in group of first 50 laboratory tests that accounted for $74 \%$ of the monthly payment (8). In that report, it was emphasized that in only one hospital, although the previous results were positive, $\mathrm{HbsAg}$ tests were repeated inappropriately 1800 times in one year. However, medical necessities were not excluded in that study. As 
a result, it was concluded that unnecessarily repeated tests should be avoided (8). In addition, when all laboratory parameters were considered, it was indicated that the repetition rates were 7.5-30\% (9). However, without setting any excluding criteria, and taking into account only the number of repetitions, accurate results for the analysis of the financial burden of the repeated tests cannot be obtained. Therefore, setting appropriate excluding criteria for calculations in repeated tests is more accurate approach.

In their study, Sharma and Salzmann (10) added warnings to the hospital network system and achieved a decrease up to $30 \%$ in repeated tests in five years. Hospital automation systems are indispensable nowadays; unnecessary repetitive tests may be prevented by the appropriate warning signals.

Many clinics and outpatient clinics were excluded from this study so to increase the sense that there was no medical necessity for repeated tests; thus, the number of repeated tests and the cost of the repeated tests could be interpreted as a clear and definite loss. In fact, this loss could be greater than we thought. This study covered data from only one hospital. Patients admitted to different hospitals might have these assays repeatedly requested. Comprehensive information pool or data processing network that gathers such data is not available yet.

In this study, it was clearly defined that inappropriately repeated tests for HBsAg, anti-HCV and anti-HIV constitute a considerable burden on our country's budget. More comprehensive survey may be conducted to analyze financial burden with the analysis of the tests in excluded group. To decrease the cost of repeated tests, firstly requesting indications and algorithms should be revised. Then, hospital networks should be connected online with other hospitals nationwide and appropriate warning signals should be placed in hospital network systems.

\section{Authorship Contributions}

Concept: Tayfur Demiray, Mehmet Köroğlu, Data Collection or Processing: Tayfur Demiray, Mehmet Köroğlu, Engin Karakeçe,
Analysis or Interpretation: Tayfur Demiray, Ahmet Özbek, Mustafa Altındiş, Literature Search: Tayfur Demiray, Mehmet Köroğlu, Writing: Tayfur Demiray, Mehmet Köroğlu, Mustafa Altındiş, Peerrewiev: External and Internal peer-reviewed, Conflict of Interest: No conflict of interest was declared by the authors, Financial Disclosure: The authors declared that this study has received no financial support.

\section{References}

1. Kwok J, Jones B. Repeat requesting of tests: an audit in a government hospital immunology laboratory. Journal Of Clinical Pathology. 2005;58(5):457-462.

2. Ağca H. Inappropriate requests of viral hepatitis serologic tests. Viral hepatit serolojik testlerinin uygunsuz istemi. 2012;3(2):181184.

3. Özbek A, Öktem Ml. Hepatit B aşılı kişilerden gereksiz test istekleri (Inappropriately ordered tests from hepatitis B vaccinated subjects). Mikrobiyoloji Bülteni. 2010;44(2):285.

4. McMahon BJ. Chronic hepatitis B virus infection. The Medical Clinics Of North America. 2014;98(1):39-54.

5. DeLemos AS, Chung RT. Hepatitis $C$ treatment: an incipient therapeutic revolution. Trends Mol Med. 2014(6):315-321.

6. Van Walraven C, Raymond M. Population-based Study of Repeat Laboratory Testing. Clin Chem. 2003;49(12):1997-2005.

7. Huissoon AP, Carlton SA. Unnecessary repeat requesting of tests in a university teaching hospital immunology laboratory: an audit. J Clin Pathol. 2002;55(1):78.

8. Cagil H, Sariyıldiz O. Biyokimya, Mikrobiyoloji ve Genetik laboratuvarlarının mevcut durumunun değerlendirilmesi ve modellenmesi. 1 ed. Ankara, Turkey: T.C. Saglık Bakanlığı Türkiye Kamu Hastaneleri Kurumu Ankara 2. Bolge Kamu Hastaneleri Birliği Genel Sekreterligi; 2013. p. 19-75, 213-9.

9. Wu AHB. Improving the utilization of clinical laboratory tests. J Eval Clin Pract. 1998;4(3):171-181.

10. Sharma A, Salzmann M. The effect of automated test rejection on repeat requesting. J Clin Pathol. 2007;60(8):954-955. 